\title{
GNIAZDA SŁOWOTWÓRCZE W BADANIACH HISTORYCZNOJĘZYKOWYCH (NA MATERIALE POLSKIEJ LEKSYKI ANIMALISTYCZNEJ) ${ }^{1}$
}

\author{
KRZYSZTOF WAŚKOWSKI \\ Uniwersytet Śląski w Katowicach \\ waskowski.krzysztof@gmail.com
}

\begin{abstract}
Nests formative in diachronic research (on the material of animal lexis)
The article presents a proposal for the use of nests word formation for the diachronic research. By using derivatives from the base $K O N$, we reconstructed panchronic nest formative, so that we could get to know the dynamics of lexis. We pointed derivations of varying degrees fixation in the history of Polish - derivatives stable, lost and new, as well as we trying to define the characteristic features of the derivation of this fragment vocabulary.
\end{abstract}

Keywords: word formation, diachrony, nest formative, lexis animal, animal names Słowa kluczowe: słowotwórstwo, diachronia, gniazdo słowotwórcze, leksyka animalistyczna, nazwy zwierząt

\section{Z żadnego punktu widzenia nie wolno być ślepym Stanisław Jerzy Lec}

Próbując opisać zjawisko językowe w ujęciu diachronicznym, historyk języka staje przed trudnym zadaniem doboru określonej metody badawczej. Problem ten wynika z braku idealnego narzędzia, które w zasadny sposób oświetlałoby wszelkie aspekty rozwoju, funkcjonowania i używania kodu naturalnego w ciągu

\footnotetext{
${ }^{1}$ Niniejszy tekst powstał w ramach projektu Stałość i zmienność polskiej leksyki animalistycznej, sfinansowanego ze środków Narodowego Centrum Nauki.
} 
wieków [por. Kleszczowa 1989: 10]. Podejmowanie trudu syntetycznego opisu historii słownictwa wymaga z jednej strony arbitralnych wyborów materiałowych, z drugiej zaś dopasowania odpowiedniej perspektywy obserwacji do wyselekcjonowanego uprzednio przedmiotu badań. Na użytek projektu Stałość i zmienność polskiej leksyki animalistycznej, realizowanego w Instytucie Języka Polskiego Uniwersytetu Śląskiego, zgromadzono materiał od okresu staropolskiego do czasów współczesnych, w skład którego weszły zarówno niepochodne nazwy zwierząt, jak i utworzone od nich derywaty. Zbiór wyrazów, wymieniony jako drugi, stanowić będzie punkt wyjścia analiz niniejszego artykułu.

Derywaty historyczne od nazw zwierząt stanowią liczny i niejednorodny zbiór, który w pobieżnym oglądzie daje obraz chaotyczny i nieuporządkowany, $\mathrm{z}$ dużą ilością elementów redundantnych. Intuicyjne poruszanie się w takim materiale jest bardzo trudne, dlatego konieczne wydało się przyjęcie określonego sposobu uporządkowania go według z góry założonego klucza. Dla analizy wyodrębnionych wyrazów pochodnych pomocne okazało się skorzystanie z propozycji słowotwórstwa gniazdowego ${ }^{2}$. Celem mojego artykułu jest próba wskazania możliwości, płynących z zaaplikowania do badań o charakterze diachronicznym metody opisu języka, wypracowanego na gruncie synchronii.

Próby zastosowania analizy gniazdowej do badań historycznojęzykowych pojawiły się na przełomie XX i XXI wieku. Pierwszym artykułem, poświęconym temu zagadnieniu był tekst Olgi Wolińskiej Możliwości zastosowania opisu gniazdowego w diachronii [1994]. W podobnym nurcie rozważań teoretycznych utrzymany został tekst Krystyny Kleszczowej Słowotwórstwo gniazdowe na ustugach lingwistyki diachronicznej [2012]33, który wnosi kilka inspirujących ustaleń metodologicznych. Przede wszystkim podkreślić należy postulatywny charakter podejścia do gniazdowej metody analizy historycznego materiału językowego. Jak zauważyła Krystyna Klesz-

\footnotetext{
2 Ów sposób posegregowania wyekscerpowanych jednostek leksykalnych był związany $\mathrm{z}$ podstawowym pytaniem o potencjał derywacyjny nazw zwierząt $\mathrm{w}$ historii języka polskiego. Warto jednocześnie dodać, że wyniki historycznych analiz gniazdowych słownictwa animalistycznego można porównać z badaniami współczesnych gniazd słowotwórczych od nazw zwierząt, opublikowanymi przez Magdalenę Wanot w artykule Vegetabilia versus animalia. Gniazda i paradygmaty stowotwórcze nazw roślin i zwierząt [Wanot 2010: 91-102].

${ }^{3}$ Artykuł po raz pierwszy ukazał się w 2007 roku w "Rozprawach Komisji Językowej Łódzkiego Towarzystwa Naukowego". W niniejszej pracy korzystamy z przedruku, umieszczonego na kartach książki Tajemnice dynamiki języka, wydanej z okazji jubileuszu pracy naukowej Profesor Krystyny Kleszczowej [Kleszczowa 2012].
} 
czowa, najprostszym sposobem na skorzystanie z ustaleń słowotwórstwa gniazdowego byłoby rekonstruowanie „analogicznych gniazd na wybranych punktach skali czasu" i zestawienie ich z XX-wiecznymi układami. Badaczka zastrzegła jednak, że sprofilowany w ten sposób ogląd prowadzić może do mało poznawczych wniosków, na co bez wątpienia wpływ ma nieporównywalna baza materiałowa uboższa dla przeszłości, zaś dla współczesności bogatsza o możliwość posłużenia się kompetencją językową ${ }^{4}$. Niepełna przystawalność materiału doprowadzi zatem do postawienia dwóch powszechnie znanych wniosków - o pomnażaniu zasobu leksykalnego polszczyzny, ale i o ekonomizacji języka, przejawiającej się przede wszystkim w usuwaniu zbędnych elementów [Kleszczowa 2012: 158-159]. W tym samym artykule Krystyna Kleszczowa zauważyła, że proces konstruowania analogicznych gniazd jest zadaniem trudnym i niezapewniającym jednoznacznych rezultatów. Dlatego też korzystanie z dorobku synchronicznego słowotwórstwa gniazdowego jako bazy materiałowej, powinno być podporządkowane z góry założonym celom. Jak pisze językoznawczyni:

\section{Gniazda słowotwórcze można traktować nie jako cel studiów diachronicz- nych, lecz jako narzędzie w dociekaniach związanych ze zrozumieniem dy- namiki słownictwa, prawideł w jego przekształcaniu się. Problem to istotny, bo, jak uczy doświadczenie, sumowanie losów poszczególnych jednostek leksykalnych nie daje oczekiwanych rezultatów, nie prowadzi do syntezy. [Kleszczowa 2012: 160]}

W myśl powyższych postulatów lingwistki powstało kilka prac szczegółowych, w których opisowi poddano poszczególne obszary leksyki. Na uwagę zasługują dwa artykułu Barbary Mitrengi: Historia gniazda słowotwórczego czasownika śniadać [2009] oraz Gniazdo stowotwórcze przymiotnika gorzki w historii języka polskiego [2010]. W pierwszym z wymienionych tekstów lingwistka zestawiła dwa gniazda słowotwórcze - jedno, zrekonstruowane z punktu widzenia diachronii, dla którego bazę stanowił czasownik śniadać, drugie, to struktura zależności derywacyjnych rzeczownika śniadanie, odtworzonych na podstawie danych, wyekscerpowanych ze słowników współczesnego języka polskiego [SJPSz, ISJP, USJP].

W zmodyfikowany w stosunku do powyższego sposób do materiału diachronicznego podeszła Barbara Mitrenga w artykule Gniazdo słowotwórcze przymiotnika

\footnotetext{
4 We wstępie do Stownika gniazd słowotwórczych [SGS] przeczytać można, że w wypadku, gdy redaktor hasła był przekonany o istnieniu derywatu nieodnotowanego w źródłach słownika [SJPDor, SJPSz, MSJP] - leksem taki wprowadzany był do schematu i opatrzony zostawał skrótem red.
} 


\title{
KRZYSZTOF WAŚKOWSKI
}

gorzki w historii jezzyka polskiego [2010]. Zrekonstruowane diachroniczne gniazdo słowotwórcze przymiotnika gorzki stanowi tu zbiór jego derywatów, które odnotowane zostały w słownikach, rejestrujących dawne słownictwo z uwzględnieniem derywatów obecnych w polszczyźnie współczesnej. Zaprezentowana metoda jest niezwykle ciekawa, wszak z sieci zależności, jakie wyznaczają wyrazy pochodne umieszczone w gnieździe, wnioskować można o ogólnych przemianach w słownictwie:

\begin{abstract}
Zaprezentowana w artykule historia gniazda słowotwórczego przymiotnika gorzki z jednej strony pokazuje, jak wielka potencja słowotwórcza tkwi w języku, jak liczna grupa wyrazów motywowanych organizowała się wokół centrum gniazda i jakie relacje wiązały poszczególne derywaty z bazą, z drugiej jednak - wskazuje na stabilność języka i formacji o ugruntowanej, zasadniczo niezmiennej semantyce i postaci słowotwórczej. [Mitrenga 2010: 21]
\end{abstract}

Z omówionego artykułu wynika nie do końca zwerbalizowana idea budowania gniazd słowotwórczych nie diachronicznych, lecz panchronicznych, skupiających leksemy, uwikłane w zależności derywacyjne, obecne w całości dziejów języka polskiego. Warto tu dodać, że istotnym uzupełnieniem w tak zrekonstruowanym układzie wyrazów byłaby informacja o chronologii notowania derywatów historycznych, tzn. podania źródła słownikowego, z którego wyekscerpowane zostały wyrazy pochodne. Rozjaśniłoby to, w moim przekonaniu, wnioskowanie o żywotności określonych form słowotwórczych w polszczyźnie i przyczyniłoby się do wskazania etapów przemian słownictwa poprzez usytuowanie ich w określonym puncie na osi czasu. Mimo tego zastrzeżenia wydaje się, że propozycja Barbary Mitrengi jest warta uwagi, gdyż umożliwia wnioskowanie o charakterze ogólnojęzykowym.

Potrzebę rekonstruowania panchronicznych gniazd słowotwórczych wyraziła już wprost Kinga Knapik w artykule Gniazdo czasownika mniemać w historii języka polskiego [2010]. W tekście tym autorka jako punkt wyjścia obserwacji historycznoleksykalnych poddała analizie „historyczne” gniazda czasowników mniemać i mnieć zestawiając je jednocześnie ze współczesną strukturą, zbudowaną wokół bazy mniemać. Jak zaznacza:

\footnotetext{
Metodologia opisu gniazdowego - właściwa gramatyce synchronicznej - może pomóc w zgromadzeniu i porównaniu słownictwa polszczyzny wieków dawnych ze stanem współczesnym. Perspektywa historyczna daje możliwość ujrzenia leksemów w pełnym bogactwie ich derywatów, a przez to pomaga dostrzec przemiany w leksyce, niewidoczne z synchronicznego punktu widzenia. [Knapik 2010: 202]
} 
Zatem wyraźnie podkreślić należy, że prócz obserwacji przemian w obrębie gniazd panchronicznych, ich wielką zaletą dla badań historycznojęzykowych jest możliwość porządkowania materiału. Historyk języka zdaje sobie sprawę z niemożliwości holistycznego ogarnięcia całego dostępnego materiału, z tego, że obserwacje historyczne wymagają odgórnie przyjętej procedury oraz odpowiedniego uporządkowania danych. Biorąc pod uwage powyższe spostrzeżenia postanowiłem zaproponować własną procedurę budowania panchronicznych ${ }^{5}$ gniazd słowotwórczych.

Rekonstruowanie gniazd słowotwórczych o charakterze panchronicznym nie jest zabiegiem łatwym. Trudności wynikające z umieszczenia derywatów w określonych miejscach w strukturze gniazda dotyczą przede wszystkim odtworzenia motywacji wyrazów pochodnych. Problem ten nabiera szczególnego wymiaru w kontekście analiz historycznojęzykowych, gdyż związany jest z brakiem źródeł i kompetencji językowej dawnych użytkowników języka [por. Kleszczowa 2012a: 215-230; Janowska, Pastuchowa 1995: 11-19]. Dlatego też konieczne są tutaj pewne uproszczenia, np. gdy mamy do czynienia z wielomotywacyjnością - kierunek derywacji określać będziemy na podstawie podobieństwa formalnego. Przykładowo dla leksemu rybnica 'sadzawka, staw rybny' przyjęliśmy motywację od leksemu rybny, zdając sobie sprawę z możliwości rzeczownikowej motywacji, co umożliwiałaby parafraza rybnica 'staw, w którym hoduje się ryby'.

Rekonstruowałem słowotwórcze gniazda panchroniczne niemotywowanych nazw zwierząt, wyekscerpowanych ze słowników rejestrujących dawne słownictwo polskie. Na użytek niniejszego opracowania zrezygnowałem

\footnotetext{
${ }^{5}$ Określenie terminologiczne panchroniczny bywa w lingwistyce różnie rozumiane. Jak podkreśla się w opracowaniach lingwistycznych, pojęcie panchronii stanowić ma rozwiązanie kluczowego dla analiz językoznawczych problemu, jaki niesie ze sobą strukturalistyczne rozgraniczenie synchronii i diachronii. Rozgraniczenie to nie było istotne dla celu przeprowadzonej analizy, można też powiedzieć, że mogłoby stanowić balast $\mathrm{w}$ kwestii oceny potencjału derywacyjnego nazw zwierząt w historii języka polskiego, wszak mogłoby prowadzić do marginalizacji istotnych faktów, ocenianych z perspektywy diachronicznej (np. tautologia lub wariantywność słowotwórcza). Jeśli jakieś zjawisko jest obserwowane w całym dziejowym przekroju z wyraźnym dążeniem do ukazania jego dynamiki (tu dynamiki derywacji od nazw zwierząt) to jedynym słusznym rozwiązaniem było przyjęcie panchronicznej perspektywy obserwacji danych. Pełny obraz wspomnianej dynamiki może dać jedynie zestawienie danych diachronicznych i synchronicznych. Zdaję sobie sprawę, że w językoznawstwie istnieje wiele definicji panchronii [por. m.in.: Łozowski 1999]. W mojej pracy ogląd panchroniczny rozumiem jako ogląd globalny, holistyczny i scalający.
} 
z klasycznego modelu gniazda słowotwórczego, jaki odnaleźć można w SGS. Przyczyną wprowadzenia zmian było bogactwo derywatów zaobserwowanych w polszczyźnie historycznej, a wprowadzone modyfikacje miały na celu stworzenie przejrzystych układów, pozwalających na łatwe dostrzeżenie zachodzących zmian. Biorąc pod uwage rodzaj części mowy, derywowany bezpośrednio od podstawy słowotwórczej i umieszczany na pierwszym takcié, wyrazy pochodne podaję w następującej kolejności:

1) rzeczowniki (zapisanie wersalikami prostą czcionką),

2) rzeczownikowe composita,

3) przymiotniki (zapisane wersalikami pochyłą czcionką),

4) przymiotnikowe composita,

5) czasowniki (zapisane wersalikami podkreśloną prostą czcionką).

Ze względu na historyczny charakter pracy, zrezygnowałem z prezentacji schematów derywacyjnych, stanowiących w SGS integralną część gniazda, umieszczaną w odrębnej kolumnie po prawej stronie artykułu hasłowego. Każdy z derywatów historycznych opatrzony został skrótem słownika, w którym został zarejestrowany: SStp, SXVI, SL, SWil, SW, SGS7. Skróty te umieszczone zostały w prawej kolumnie gniazda. Dane, pozyskane z leksykonów, zostały uzupełnione o leksemy, wyekscerpowane z kartoteki SXVI (skrót KSXVI) ${ }^{8}$. Przy symbolach słowników podaję, jeśli występują, kwalifikatory, odnoszące się do poszczególnych wyrazów pochodnych.

\footnotetext{
${ }^{6} \mathrm{~W}$ założeniach słowotwórstwa gniazdowego jako takt derywacyjny rozumie się odległość wyrazu pochodnego od centrum gniazda. Przykładowo derywat koni-ę znajduje się na pierwszym takcie derywacyjnym względem bazy koń, derywat koni-ątko na drugim takcie derywacyjnym względem bazy koń oraz na pierwszym takcie derywacyjnym względem swojej bezpośredniej podstawy koni-ę. Zatem poszczególne takty derywacyjne wskazać można w strukturze gniazda na podstawie analizy stopnia pochodności, tzw. układu schodkowego.

7 Zaproponowana metoda chronologizacji danych, opierająca się na przytaczaniu skrótów słowników, w których odnotowane zostały określone derywaty, tylko w sposób orientacyjny pozwala umieścić na osi czasu poszczególne wyrazy pochodne (powszechnie wiadomo przecież, że Słownik języka polskiego Samuela Bogumiła Lindego rejestruje materiał od wieku XVI do początku wieku XIX, zaś w słowniku tzw. warszawskim powtarza się część leksyki za słownikiem Lindego). W niniejszych badaniach wydaje się ona wystarczająca. Warto jednak zaznaczyć, że dla określenia cezury czasowej pewniejsze by było posłużenie się informacjami na temat źródeł cytowań i wskazanie konkretnych stuleci występowania badanych struktur.

8 W celu pozyskania danych, odnoszących się do nieopracowanych jeszcze haseł, korzystałem z toruńskiej kartoteki tego słownika.
} 
Przyjęta procedura rekonstruowania panchronicznych gniazd słowotwórczych umożliwiła sporządzenie następującego układu derywatów ${ }^{9}$ :

\section{Panchroniczne gniazdo słowotwórcze z bazą KOŃ}

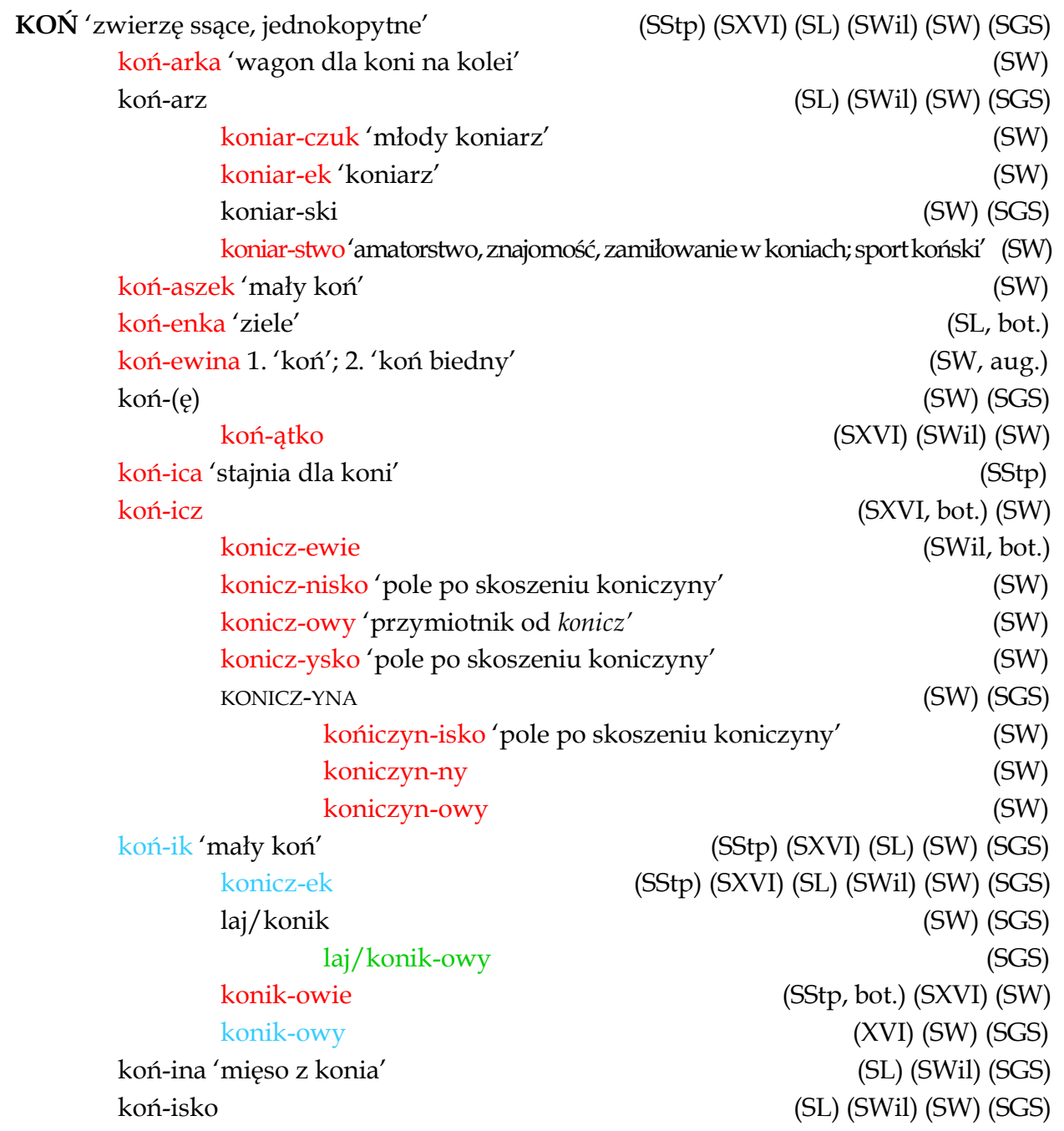

${ }^{9}$ Ze względu na ograniczoną objętość artykułu prezentuję tylko jedno zrekonstruowane gniazdo. Nieprzypadkowo jest to struktura zależności derywacyjnych z centrum KOŃ - ta okazała się najbardziej reprezentatywna. W dalszej części tekstu będę przytaczać przykłady z innych gniazd. 


\section{KRZYSZTOF WAŚKOWSKI}

koń-iszek

(SW)

koń-iś

(SW)

koń-owa 'samica konia' uż. rzecz.

(SXVI) (SWil) (SW)

koń-uch

(SL) (SWil) (SW) (SGS)

koń-usz

(SStp) (SXVI)

konius-two

(SW)

koniusz-ek

(SStp) (SXVI)

końusz-nik

(SW)

koniusz-anka 'córka koniuszego'

(SL) (SW)

koniusz-ostwo

koniusz-ować ‘być koniuszym'

koniuszow-anie

koniusz-owski

(SL) (SWil)

koniusz-y

koniusz-yc 'syn koniuszego'

$$
\text { koniuszyc-owa 'żona koniuszego' }
$$

(SXVI) (SL) (SWil) (SW) (SGS)

(SWil) (SW)

(SW)

koniusz-yna 'żona koniuszego'

(SL) (SWil)

koniusz-ystwo

pod-koniuszy

(SL) (SGS)

podkoniusz-ostwo

(SGS, hist.)

podkoniusz-yc

(SL) (SWil)

kon-o-wał 'osoba zajmująca się kowalstwem i leczeniem koni'

kon-o-wiąz 'urządzenie do przywiązywania koni'

koń-i-ogon

(SL) (SWil)

koń-i-trut

(SXI, bot.) (SL, bot.) (SW, bot.)

kon-i-strach

(SL, bot.) (SWil, bot.) (SW)

koń-i-szał

(SW, bot.)

koń-o-bieg 'miejsce gonitw końskich'

(SL) (SWil) (SW)

koń-o-bójnia 'rzeźnia do zabijania koni'

koń-o-chrom

(SStp, bot.)

koń-o-człowiek 'giermek, laufer'

koń-o-godzina

koń-o-gryf 'ptak bajeczny'

(SW)

koń-o-jad 'ten, co jada konie'

koń-o-krad

(SW) (SGS)

koniokrad-ca

koniokradz-two

(SW) (SGS)

koń-o-mania

koń-o-ogon

(SW, bot.)

koń-o-płoch

(SL, bot.) (SWil, bot.) (SW, bot.) 


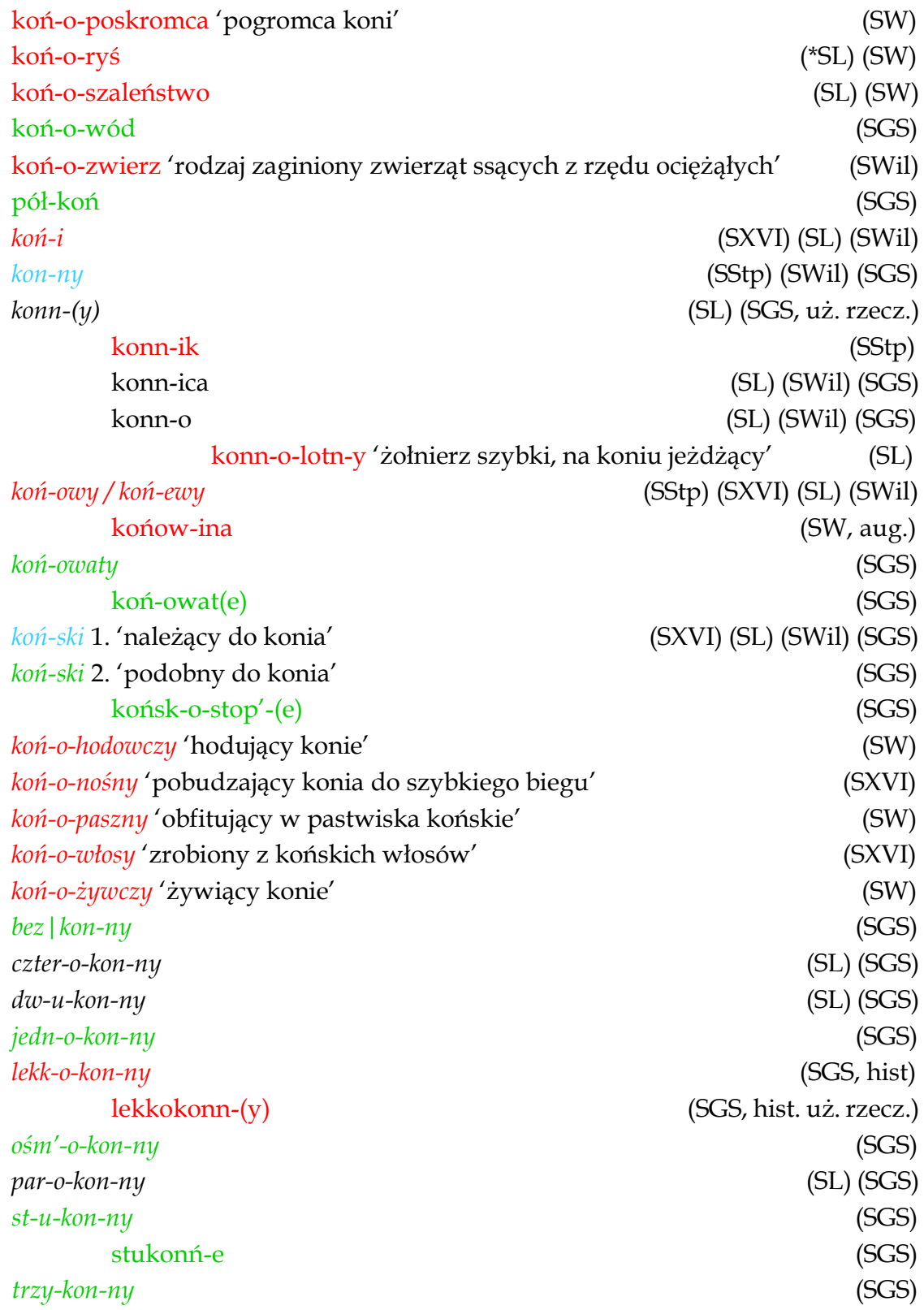

koń-ski 1. 'należący do konia'

koń-ski 2. 'podobny do konia' końsk-o-stop'-(e)

koń-o-hodowczy 'hodujący konie'

koń-o-nośny 'pobudzający konia do szybkiego biegu'

koń-o-paszny 'obfitujący w pastwiska końskie'

koń-o-włosy 'zrobiony z końskich włosów'

koń-o-żywczy 'żywiący konie'

bez|kon-ny

czter-o-kon-ny

dw-u-kon-ny

jedn-o-kon-ny

lekk-o-kon-ny lekkokonn-(y)

ośm'-o-kon-ny

par-o-kon-ny

st-u-kon-ny

(SXVI) (SL) (SWil) (SGS)

W tym miejscu, ze względu na ograniczoną objętość artykułu, ograniczam się do wymienienia tylko wybranych problemów, jakie zinterpretować można za pomocą proponowanej metody. Jak już wspomniałem, zasadnicza korzyść 
płynąca z gniazdowej analizy historycznych derywatów to szansa na uporządkowanie danych, rozproszonych w różnych dostępnych źródłach. Zestawiając wyrazy pochodne $\mathrm{w}$ zhierarchizowane układy, można wydobyć porządek z chaosu zbioru różnorodnych jednostek leksykalnych. Już samo umieszczenie derywatów w konkretnych miejscach gniazda porządkuje leksemy pochodne poprzez odniesienie ich do leksemów motywujących i odzwierciedla zależności derywacyjne. Poprzez umieszczenie informacji na temat obecności leksemów w określonych słownikach możliwe jest również wskazanie okresu nasilania się pewnych tendencji, jak np. przyrost wyrazów złożonych o charakterze okazjonalnym w okresie od XVII do początku XX wieku - SL i SW notują wiele jednostek leksykalnych tego typu, które nie występowały wcześniej i zaniknęły wraz z początkiem dwudziestego stulecia ${ }^{10}$.

Zaproponowany sposób obserwacji wyrazów pochodnych od nazw zwierząt umożliwia śledzenie stabilnych i zmiennych elementów badanego pola leksykalnego. Orzekanie o stabilności i zmienności wyrazów zawsze budzić może wątpliwości i powodować komplikacje. Oceniając dziedzictwo leksykalne, należałoby rozpatrywać tożsamość formy i treści słowa. Jednak - przyjmując takie założenie w perspektywie historycznojęzykowej - musielibyśmy uznać wszystkie leksemy za zmienne, wszak wartości znaczeniowe zawsze ulegają modyfikacjom i zależne są od określonej sytuacji komunikacyjnej, kontekstu, rodzaju tekstu, w jakim występują itp. [Kleszczowa 2012c: 252]. Ustalenie stabilnej lub zmiennej pozycji leksemu wymaga zatem arbitralnych założeń ${ }^{11}$. W przypadku przeprowadzonej

\footnotetext{
10 Może to wynikać z typów słowników. Wiadomo, że Słownik Lindego, ale także warszawski, podawały okazjonalizmy i wyrazy o nieustabilizowanej pozycji.

11 Artur Rejter, badając ekspresywne apelatywne nazwy osób wyznaczył trzy poziomy stabilnych znaków języka. Za leksemy charakteryzujące się pełną stabilnością uznał wyrazy pozostające w słowniku w niezmiennym znaczeniu i zachowujące nacechowanie ekspresywne, za leksemy względnie stabilne - jednostki ulegające pewnej modyfikacji semantycznej i/lub formalnej, ale zachowujące nacechowanie emocjonalne, zaś za wyrazy potencjalnie stabilne - leksemy, które mogą zostać utworzone w każdej chwili w określonej postaci i funkcji ekspresywnej [Rejter 2006: 174-175]. Teresa Smółkowa do wyrazów stabilnych w polszczyźnie zalicza część współcześnie używanej leksyki, „która jest obecna w zasobie leksykalnym polszczyzny od dłuższego czasu i była znana co najmniej kilkunastu pokoleniom Polaków poprzedzających najstarsze z obecnie żyjących" [Smółkowa 1998: 428-429] i zastrzega jednocześnie, że elementy tak wyznaczonego zbioru mogą się od siebie różnić długością leksykalnego istnienia. Lingwistka słusznie zaliczyła do najstarszych leksemy związane z religią, wiarą, stopnie pokrewieństwa, czy też leksemy należące do pól „rośliny”, ,"zwierzęta”, , ciało człowieka i jego części”, , „religia i wiara”, ,przyroda nieożywiona”.
} 
analizy określenie, czy dana jednostka leksykalna jest stabilna lub zmienna ułatwia śledzenie sporządzonych schematów derywacyjnych: kolorem niebieskim zapisałem derywaty w pełni stabilne, tzn. takie, które trwają w polszczyźnie od staropolszczyzny lub XVI w. w mniej więcej niezmiennej postaci formalnosemantycznej, kolorem czarnym - derywaty o względnej stabilności, tzn. takie, które notowane są w SGS oraz słownikach historycznych, lecz nie występują w SStp i SXVI, kolorem czerwonym - leksemy zaginione, tzn. takie, które nie są odnotowane w SGS lub odnotowane są z kwalifikatorem chronologicznym (przestarz., hist., ksiażk., daw.), kolorem zielonym zapisałem nowe jednostki leksykalne, tzn. takie, które odnotowane są tylko w SGS. Za pomocą KAPITALIKÓw sygnalizuję leksemy, które współcześnie stanowią centra odrębnych gniazd słowotwórczych. Wyodrębnienie tych grup leksemów ułatwia wskazanie przyczyn dynamiki słownictwa w badanym polu.

Zrekonstruowane panchroniczne gniazda słowotwórcze pozwalają na wskazanie cech derywacji w polu nazw zwierząt. Formanty, za pomocą których utworzone zostały wyrazy pochodne w dawnej polszczyźnie, charakteryzują się polifunkcyjnością. W większości tworzą derywaty polisemiczne, na przykład leksem rybitwa miał znaczenia 'ptak', 'czynność łowienia ryb' oraz 'ten, kto zajmuje się łowieniem ryb'; psiniec 'pies szkaradny' oraz 'psie łajno'. Jednostki leksykalne, charakteryzujące się wieloznacznością, z biegiem lat ograniczały pierwotną polisemię na rzecz umocnienia się jednego, głównego znaczenia wyrazu w polszczyźnie ogólnej. Przykładowo w USJP odnajdujemy niektóre wskazane wyrazy o jednej już wartości znaczeniowej np.: rybitwa 'Sterna, ptak podobny do mewy, o prostym dziobie, długich, wąskich skrzydłach i rozwidlonym ogonie, żyjący nad brzegami mórz i wśród wód śódlądowych, polujący na ryby, skorupiaki i owady'.

W zrekonstruowanych panchronicznych gniazdach zauważyłem nagromadzenie synonimów słowotwórczych. Zwraca uwagę duża liczba tych jednostek leksykalnych w historii, zaś analiza układów derywatów umożliwia wskazanie różnych źródeł synonimii w badanym polu leksykalnym. Pobieżna obserwacja pozwoliła stwierdzić, że charakteryzują się one różnym statusem formalnym. Jak się okazuje, elementy tego zbioru były w dużej mierze redundantne i z biegiem wieków wycofywały się z języka. Wydzieloną grupę jednostek leksykalnych można podzielić na kilka zbiorów:

a) formacje synonimiczne wobec podstawy słowotwórczej, inaczej nazywane derywatami tautologicznymi. Mimo iż powszechnie uważa się, że 
zjawisko tautologii jest charakterystyczne dla staropolszczyzny12, na podstawie zgromadzonego materiału stwierdzić można, że dotyka ono, co prawda z mniejszym nasileniem, również wieków późniejszych. W interesujących nas gniazdach status derywatów tautologicznych można przykładowo przypisać następującym parom: szarańczak [SGS] od szarań$c z a$ [SL, SW, SGS], skopiec [SStp, KSXVI, SL, SW] od skop [SStp, KSXVI, SL, SGS], skopek [SL, SW, SGS 1. rząd.] od skop [SStp, KSXVI, SL, SGS], koniusznik [SW] od koniusz [SStp, SXVI], koniuszy [SXVI, SL, SWil, SW, SGS] od koniusz [SStp, SXVI], psiarczyk [SW] od psiarek [SW, SGS].

b) synonimiczne jednostki leksykalne charakteryzujące się tożsamością podstaw oraz wariantywną postacią formantów: koniuszostwo - koniuszystwo, koniewina - koniowina. Elementy zbioru, utworzone za pomocą nieustabilizowanych formantów, wycofywały się z użycia wraz z rozwojem polskiej derywacji.

c) synonimy utworzone od tej samej podstawy słowotwórczej za pomocą różnych formantów, gdzie tożsamość znaczeń par derywatów była wynikiem niewyspecjalizowania się znaczeniowego afiksów, możliwości zastosowania różnych modeli słowotwórczych, różnic regionalnych itp., np.: skopny - skopowy 'przymiotnik od skop', psarz / psiarz- psiacz 'ten, kto zajmuje się psami', piesak - piesek 'dem. od pies', psiarnia - psiarstwo 'zgraja psów', rybnik - rybnica 'sadzawka, w której hoduje się ryby'.

d) synonimy motywowane przez różne jednostki leksykalne, często znajdujące się na różnych taktach derywacyjnych tego samego gniazda: rybaczka (od rybak) - rybiarka (od rybiarz), rybak (od ryba) - rybaczyk (od rybak), koniuszycowa (od koniuszyc) - koniuszyna (od koniuszy lub koniusz), koniusz (od koń) - koniusznik (od koniuszy lub koniusz).

\footnotetext{
$12 \mathrm{O}$ derywacji tautologicznej mówimy wtedy, kiedy formant tworzący wyraz pochodny jest neutralny semantycznie i nie wnosi modyfikacji znaczenia formacji słowotwórczej względem jej podstawy. Krystyna Kleszczowa zauważyła, że „skala omawianego zjawiska jest duża w staropolszczyźnie" [Kleszczowa 1998: 37; por. również Pastuchowa 1994: 78-84, Winiarska-Górska 2010: 417-441]. Przykładowo możemy wskazać formacje obecne w najstarszej warstwie polszczyzny: czyrwiec (czerwiec) od czyrw (czerw) 'owad wytwarzający barwnik czerwony' [SStp], cielec od ciele [SStp], ciotek od ciele [SStp], giezek 'giez' od giez [SStp], (jażdzyk) jeżdżyk 'ryba jazgarz' od jażdż [SStp], jesietrzec 'jesiotr' od jesiotr 'jesiotr' [SStp], jeżyk 'jeż' od jeż 'jeż' [SStp], koźlec od koziot [SStp], liszka 'lis' od lis 'lis' [SStp], osiełek (osiołek) 'osioł' od osiet (osiot) [SStp], pijawica od pijawka [SStp], ptocica od ptoć [SStp].
} 
W gniazdach motywowanych przez nazwy zwierząt odnajdujemy w historii polszczyzny dużą liczbę compositów. Zaprzecza to sądowi, że kompozycja jest charakterystyczną cechą nowszej warstwy słownictwa [Satkiewicz 1969: 71]. Raczej należałoby powiedzieć, że jest typowym i powszechnym zjawiskiem dla języków słowiańskich, której źródła tkwią w języku prasłowiańskim [Handke 1976: 6]. Kompozycja stanowi więc istotny sposób pomnażania leksyki. Przykładowo warto podać, że w gnieździe z centrum KOŃ odnotowano 25 compositów, w gnieździe z centrum RYBA - 36, w gnieździe z centrum PIES - 2013. O dużej mocy nominacyjnej wyrazów złożonych świadczyć może również fakt, że tworzyły nowe gniazda słowotwórcze, por.: koniokrad, koniokradca, koniokradztwo; rybołów, rybołowca, rybołowek, rybołowny, rybołówczy, rybołówek, rybołówka, rybołówstwo; psiakrew, psiakrwować, psiakrwowanie.

W grupie derywatów od nazw zwierząt wskazać można sporą liczbę wyrazów o niewielkiej frekwencji, sprawiających niekiedy wrażenie formacji okazjonalnych. Trudno, niekiedy wręcz niemożliwe, jest określenie ich statusu słowotwórczego. Niektóre elementy systemu derywacyjnego w obrębie gniazd słowotwórczych, motywowanych przez nazwy zwierząt, należy obserwować nie z perspektywy słowotwórstwa, lecz zjawisk leksykalnych ${ }^{14}$. Trudno jest wskazać jednoznacznie przyczyny powstania w historii polszczyzny wyrazów okazjonalnych, utworzonych od

\footnotetext{
13 Wskazane powyżej statystyki mają charakter jedynie orientacyjny. Uświadamiają jednak skalę zjawiska w dziejach polskiej leksyki animalistycznej. Podkreślić jednak należy, że composita te w znacznej mierze maja charakter okazjonalny, mogą stanowić efekt zapożyczeń, bądź kalk leksykalnych. Już w połowie ubiegłego wieku Irena Klemensiewiczówna zauważyła: „Kwestię rodzimości wyrazów złożonych trzeba by zbadać z uwzględnieniem tła historycznego. Wiadomo, że wśród wyrazów złożonych spotykamy liczne tzw. kalki czy to bardzo starożytne, jak np. bogarodzica (z grec. veó $\tau o \chi 0 \varsigma$ ), rzeczpospolita (łac. res publica); czy też stosunkowo młodziutkie, jak listonosz (niem. Briefträger) i światopogląd (niem. Weltanschauung). Szczególnie dużo $<<$ kalek $>>$ w słownictwie naukowym, gdzie wiele wyraźnie nieudanych i rażących nazw zrodziło się ze szlachetnych w założeniu prób spolszczenia słownictwa naukowego" [Klemensiewiczówna 1951: 112-113]. Rozważania tego typu mieszczą się wprawdzie poza tematem niniejszego artykułu, niemniej problemowi warto przyjrzeć się bliżej [por. też na ten temat: Walczak 2000; Obara 1989].

14 Na problem opisu jednostkowych faktów leksykalnych zwróciła już uwagę Aleksandra Janowska, podkreślając bardzo wyraźnie, że pojedyncze leksemy, zdawać by się mogło - zupełnie przypadkowe, w żaden sposób nie można przyporządkować do regularnych kategorii czy klas, a wyznaczenie granicy pomiędzy zjawiskami natury słowotwórczej i leksykalnej jest niekiedy niemożliwe, wszak prowadzi do znacznych uproszczeń i zamazuje rzeczywisty obraz [Janowska 2007b: 115].
} 
nazw zwierząt. Jak podkreśliła Aleksandra Janowska w tekście o czasownikach staropolskich, pojawienie się wyrazów potencjalnych spowodowane jest działaniem różnorodnych mechanizmów, które najogólniej nazwać możemy analogią [Janowska 2007b: 116]. Do grupy tej możemy zaliczyć takie jednostki leksykalne, dla których jesteśmy w stanie wskazać wzór konstrukcji, np. psiniec 'psie łajno' [SW] na wzór krowiniec 'krowi nawóz', kobyliniec 'koński nawóz' itp.

Derywaty o charakterze okazjonalnym, odnotowane w polu leksyki animalistycznej, to najczęściej formacje ekspresywne oraz utworzone doraźnie na potrzeby konkretnej wypowiedzi: koniewina / koniowina [SW], koniszek [SW], psiniec [SW], rybina [SW], rybsko [SL, SW]. Uderza spora ilość formacji złożonych: konioposkromca [SW], konioszaleństwo [SW], koniomania [SL, SWil], koniobójnia [SW], koniojad [SW], koniowtosy [SXVI], koniopaszny [SW], koniohodowczy [SW], konionośny [SXVI], rybostan [SW], psiabestia [SL, SW], psibiskunt [SW], psianoga [SW] rybowieszczek [SL, SW], konioposkromca 'pogromca koni' [SW], koniożywczy 'żywiący konie' [SW], koniowłosy 'zrobiony z końskich włosów' [SXVI], rybowieszczek 'wieszczący z ryb' [SW], rybook 'kamień rybiemu oku podobny' [SL, SW]. Podobnych przykładów można wskazać więcej. Podstawową cechą tej grupy wyrazów jest jednostkowość ich użycia oraz nieustabilizowanie w normie językowej, często notowane są tylko w jednym z leksykonów poddanych ekscerpcji.

Zaprezentowana gniazdowa analiza diachronicznego materiału leksykalnego stanowi propozycję badań dynamiki słownictwa. W krótkim tekście nie sposób wymienić wszystkich korzyści, płynących z przyjętej perspektywy obserwacji danych językowych, wyakcentowałem natomiast te, które ważne są dla realizowanego przeze mnie projektu Stałość i zmienność polskiej leksyki animalistycznej. Zaproponowany sposób obserwacji może być pomocny nie tylko w rozumieniu procesów leksykalnych i wskazaniu ich przyczyn, lecz umożliwia również właściwą segmentację materiału, ułatwiającą poruszanie się po „grząskim gruncie źródeł i faktów historycznojęzykowych" [Kleszczowa 2012c]. 


\section{Bibliografia}

\section{Słowniki}

ISJP: Inny słownik języka polskiego, red. M. Bańko, t. 1-2, Warszawa 2000: Wydawnictwo Naukowe PWN.

SGS: Słownik gniazd stowotwórczych wspótczesnego języka ogólnopolskiego, t. 2: Gniazda odrzeczownikowe, Kraków 2001: Universitas.

SL: Stownik jezzyka polskiego, B. S. Linde, Warszawa 1807-1814.

SSTP: Stownik staropolski, red. S. Urbańczyk, t. 1-11, Warszawa - Wrocław - Kraków 1966-2000: IJP PAN.

SJPSz: Słownik języka polskiego, red. M. Szymczak, t. 1-3, Warszawa 1996: Wydawnictwo Naukowe PWN.

SW: Słownik języka polskiego, red. J. Karłowicz, A. Kryński, W. Niedźwiedzki, t. 1-8, Warszawa 1900-1927.

SWIL: Słownik jezzyka polskiego, red. A. Zdanowicz, M. Bohusz-Szyszka, t. 1-2, Wilno 1861.

SXVI: Słownik polszczyzny XVI wielu, red. M.R. Mayenowa, Wrocław- WarszawaKraków 1966: Ossolineum.

USJP: Uniwersalny słownik jezzyka polskiego, S. Dubisz, Warszawa 2003: Wydawnictwo Naukowe PWN.

\section{Opracowania}

JANOWSKA A., 2007: O roli analogii w słowotwórstwie (na przykładzie czasowników staropolskich), „LingVaria”, nr 2, s. 115-120.

JanOWSKA A., PASTUChOWA M., 1995: Niebezpieczna kompetencja, „Poradnik Językowy", z. 8, s. 11-19.

KLESZCZOWA K., 2012: Stowotwórstwo gniazdowe na ustugach lingwistyki diachronicznej, w: Tajemnice dynamiki języka. Księga jubileuszowa, red, A. Janowska, M. Pastuchowa, Katowice, s. 157-172.

KLESZCZOWA K., 2012a: O historycznej ciąłości kompetencji językowej, w: Tajemnice dynamiki jezzyka. Księga jubileuszowa, red. A. Janowska, M. Pastuchowa, Katowice, s. 215-230.

KLESZCZOWA K., 2012b: Zanikanie słów wobec ewolucji systemu słowotwórczego, w: Tajemnice dynamiki jezyka. Księga jubileuszowa, red. A. Janowska, M. Pastuchowa, Katowice, s. 251-260. 


\section{KRZYSZTOF WAŚKOWSKI}

KLESZCZOWA K., 2012c, Grząski grunt źródet i faktów historycznojęzykowych, w: Tajemnice dynamiki jezzyka. Księga jubileuszowa, red. A. Janowska, M. Pastuchowa, Katowice, s. 47-56.

KLESZCZOWA K., 1998: Staropolskie kategorie słowotwórcze i ich perspektywiczna ewolucja. Rzeczowniki, Katowice.

KLESZCZOWA K, 1989: Verba dicendi w historii jezyka polskiego. Zmiany znaczeń, Katowice.

KNAPIK K., 2010: Gniazdo czasownika mniemać w historii języka polskiego, „Poznańskie studia językoznawcze. Seria językoznawcza”, nr 17 (37), s. 193-203.

MitrenGA B., 2009: Historia gniazda stowotwórczego czasownika śniadać, w: Jezzyk z różnych stron widziany, red. M. Skarżyński, A. Czelakowska, Kraków, s. 201-208.

MitrengA B., 2010: Gniazdo słowotwórcze czasownika gorzki w historii języka polskiego, w: Bogactwo polszczyzny w świetle jej historii, t. 3., red. A. Rejter, Katowice, s. 13-24.

PASTUCHOWA M., 1994: O pewnej funkcji sufiksu -ek w staropolszczyźnie, „Prace Językoznawcze", T. 22: Studia historycznojęzykowe, red. A. Kowalska, Katowice, s. 78-84.

REJTER A., 2006: Leksyka ekspresywna w historii jezyka polskiego. Kulturowo - komunikacyjne konteksty potoczności, Katowice.

SMÓŁKOWA T., 1998: Słownictwo - zmienność i stabilność, „Prace Filologiczne”, T. 43, Warszawa, s. 425-431.

WANOT M., 2010: Vegetabilia versus animalia. Gniazda i paradygmaty słowotwórcze nazw roślin i zwierząt, "LingVaria”, nr 1 (9), s. 91-102.

WINIARSKA-GÓRSKA I., 2010: Uwagi o staropolskich dubletach typu cielec - ciołek, bracieniec - bracianek, w: Słowa - kładki, na których spotykaja się ludzie różnych światów, red. I. Burkacka, R. Pawelec, D. Zdunkiewicz-Jedynak, Warszawa, s. 417-441.

WOLIŃSKA O., 1994: Możliwości zastosowania opisu gniazdowego w diachronii, „Poradnik Językowych" z. 5-6, s. 63-69. 


\section{Gniazda słowotwórcze w badaniach historycznojezykowych}

(na materiale polskiej leksyki animalistycznej)

\section{(streszczenie)}

W artykule przedstawiono propozycję zastosowania słowotwórstwa gniazdowego do badań o charakterze historycznojęzykowym. Wykorzystując derywaty od bazy KOŃ, zrekonstruowano panchroniczne gniazdo słowotwórcze, na podstawie którego można było orzekać o dynamice słownictwa. Wskazano wiec wyrazy pochodne o różnym stopniu utrwalenia w dziejach polszczyzny - derywaty stabilne, zaginione oraz nowe, jak również próbowano określić charakterystyczne cechy derywacji omawianego fragmentu słownictwa. 